\title{
HUBUNGAN FOOTWORK, KEKUATAN OTOT TUNGKAI DAN TINGGI LOMPATAN TERHADAP KEMAMPUAN SMASH BULUTANGKIS
}

\author{
Gusti Pramudeka Gustaman
}

Pendidikan Jasmani, Kesehatan dan Rekreasi, STKIP Muhammadiyah Kuningan

email: gustypranurdekagustaman15@gmail.com

\begin{abstract}
Info Artikel
\section{Abstrak}

Sejarah Artikel:

Diterima November 2018

Tujuan dari penelitian ini untuk memperoleh gambaran objektif tentang

Disetujui Desember 2018 hubungan antara footwork, kekuatan otot tungkai dan tinggi lompatan terhadap kemampuan smash. Metode yang digunakan dalam penelitian ini adalah metode eksperimen dengan uji korelasi. Populasi dan sampel

Dipublikasikan Januari 2019 dalam penelitian ini sebanyak 10 atlet putra. Instrumen yang digunakan dalam penelitian adalah tes shuttlerun, leg-press, vertical jump,

Keywords:

Footwork, Kekuatan, Otot tungkai, Tinggi Lompatan, Smash

Hubungan footwork dengan kemampuan smash adalah sebesar 0,81 (65,61\%). Sehingga hubungan footwork dengan kemampuan smash signifikan dan intrepentasi nya sangat kuat. Hubungan kekuatan otot tungkai dengan kemampuan smash adalah sebesar 0,81 (65,61\%). Sehingga terdapat hubungan kekuatan otot tungkai dengan kemampuan smash signifikan dan intrepentasinya sangat kuat. Hubungan tinggi lompatan dengan kemampuan smash adalah sebesar 0,85 (72,25\%). Sehingga terdapat hubungan tinggi lompatan dengan kemampuan smash signifikan dan intrepentasi nya kuat. Maka dapat dinyatakan bahwa terdapat hubungan yang signifikan antara footwork, kekuatan otot tungkai dan tinggi lompatan terhadap kemampuan smash. Kesimpulan dari penelitian ini adalah latihan footwork, kekuatan otot tungkai dan tinggi lompatan dapat meningkatkan hasil kemampuan smash.
\end{abstract}

\begin{abstract}
The aim of this study was to obtain an objective picture of the relationship between footwork, leg muscle strength and a high leap to smash ability. The method used in this study is the experimental method with a correlation test. The population and sample in this study were 10 male athletes. The instruments used in the study were shuttle run, leg-press, vertical jump, footwork and abilities smash of 0.81 (65.61\%). So that the relationship of footwork with the ability is smashed significant and the interpretation is very strong. The relationship of leg muscle strength with ability smash was 0.81 (65.61\%). So that there is a relationship between leg muscle strength with the ability to smash significant and very strong interpretation. The relationship between height jump and ability smash is 0.85 (72.25\%). So there is a high leap relationship with significant smash ability and strong interpretation. Then it can be stated that there is a significant relationship between footwork, leg muscle strength and a high
\end{abstract}


jump to ability smash. The conclusion of this study is exercise footwork, leg muscle strength and high jump can increase the results of smash ability.

(C) 2019 Gusti Pramudeka Gustaman Under the license CC BY-SA 4.0

$\bowtie$ Alamat korespondensi: ISSN 2655-1896 (online)

E-mail : gustypranurdekagustaman15@gmail.com ISSN 2443-1117 (cetak)

No Handphone : 085797070700 


\section{PENDAHULUAN}

Bulutangkis di Indonesia mengalami pertumbuhan yang sangat pesat, ini terbukti dengan munculnya pebulutangkis muda berbakat yang dapat terjun secara langsung dalam dunia pebulutangkisan Indonesia. Selain itu terbukti dengan munculnya pebulutangkis muda berbakat yang dapat terjun langsung dalam dunia pebulutangkisan Indonesia. Untuk itu perlu disiapkan atlet, pelatih dan organisasi yang berkulitas serta perencanaan program yang tepat sehingga dapat menciptakan pemain bulutangkis generasi baru yang mampu menguasai teknik, dan taktik yang baik.

Olahraga prestasi adalah kegiatan olahraga dan dikelola secara profesional dengan tujuan untuk memperoleh prestasi optimal pada cabang-cabang olahraga. Atlet yang menekuni salah satu cabang tertentu untuk meraih prestasi, dari mulai tingkat daerah, nasional dan internasional mempunyai syarat memiliki teknik yang mempuni dan tingkat kebugaran yang tinggi. Faktor teknik dasar dalam olahraga sangat berpengaruh terhadap suatu keberhasilan untuk mencapai prestasi, teknik dasar yang dimaksud adalah teknik dasar permainan bulutangkis khususnya pukulan smash yang mana teknik pukulan smash adalah salah satu teknik dasar serangan dalam permainan bulutangkis.

Pemain bulutangkis yang baik diperlukan dukungan kemampuan fisik yang baik. Misalnya dalam rangkaian gerak smash ada beberapa rangkaian gerak yang sangat membutuhkan kondisi fisik yang sangat baik, contoh dalam gerakan footwork smash (gerakan mundur tiga langkah dan kemudian maju satu langkah sebelum kemudian memukul bola) dan melakukan pukulan yang keras dalam smash. Kemudian dalam jumping smash gerakan footwork dan vertical jump dan kemudian melakukan pukulan dalam jumping smash, dalam pertandingan gerakan-gerakan itu sangat sering dilakukan pebulutangkis maka dari itu pemain bulutangkis sangatlah membutuhkan kemampuan fisik yang sangat baik.
Footwork merupakan salah satu komponen fisik yang banyak dipergunakan dalam olahraga. Footwork pada umumnya didefinisikan sebagai kemampuan mengubah arah secara efektif dan cepat, sambil berlari hampir dalam keadaan penuh. Footwork menurut Poole, (2007:255) adalah cara mengatur kaki yang sangat diperlukan oleh pemain bulutangkis. Cara mengatur kaki sangat penting karena seorang pemain tidak mungkin memukul shuttlecock dengan efisien ataupun mengontrol lawan apabila tidak dapat dengan mudah berada pada posisi untuk memukul. Dengan langkah kaki (footwork) yang efektif dan efisien, akan mempermudah untuk bergerak di setengah lapangan bulutangkis, sehingga stamina dan tenaga yang diperlukan akan lebih kecil.

Otot tungkai merupakan alat gerak yang digunakan untuk menggerakan otototot bagian kaki dalam tubuh seorang atlet bulutangkis. Otot tungkai memiliki banyak otot yang terdapat pada tungkai, dilakukan dengan tujuan untuk mengetahui hubungan yang signifikan antara kekuatan otot tungkai dan kelentukan dengan kemampuan smash. Menurut Gardner dkk dalam Ridwan (2010:10-11), Berkaitan dalam halnya anggota tubuh bagian atas, anggota tubuh bagian bawah di hubungkan dengan badan oleh sebuah sendi yang terdiri dari tiga bagian, yaitu tungkai atas, tungkai bawah dan kaki. Otot tungkai sebagai faktor yang mempengaruhi kemampuan smash dalam permainan bulutangkis maka perlu diadakan suatu penelitian tentang hal ini. Peran otot tungkai dalam kemampuan smash bulutangkis sangatlah penting dan membantu dalam kemampuan smash terhadap permainan bulutangkis. Menurut Ismaryati (2006:59) bahwa otot tungkai menyangkut kekuatan dan kecepatan kontraksi otot yang dinamis serta melibatkan pengeluaran kekuatan otot yang maksimal dalam waktu yang secepatcepatnya.

Tinggi lompatan adalah suatu gerakan mengangkat tubuh dari suatu titik ke titik lain dengan tumpuan satu kaki dan 
mendarat dengan kaki. Dalam permainan bulutanglis tinggi lompatan juga termasuk salah satu hal penting untuk mencapai suatu kemampuan smash. Salah satunya untuk mencapai hasil kemampuan smash harus melakukan tes kebugaran dengan vertical jump yang sudah umum dilakukan untuk menentukan otot kaki seorang atlet. Lovitt (2004:39). Berdasarkan Observasi dan pengamatan permasalahan dalam penelitian ini bahwa pebulutangkis Junior di PB Sanggariang mempunyai teknik dasar yang baik dari mulai cara memegang raket (Grips), gerakan melangkah kaki (Footwork), teknik penguasaan pukulan (Strokes) dan teknik menguasai pola-pola pukulan (Servic, Lob, Dropshort, Drive Dan Smash).

Namun tidak semua pebulutangkis di PB Sanggariang memiliki kondisi fisik yang baik hal ini terlihat ketika pada saat latihan teknik maupun latihan uji tanding. Dibalik itu ada suatu masalah yang paling penting terutama dalam penelitian yang harus saya teliti di PB Sanggariang Kuningan tersebut, yaitu salah satunya adalah footwork, kekuatan otot tungkai dan tinggi lompatan terhadap kemampuan smash. Latihan ini saya lihat sangat kurang dalam setiap atlet yang ada di PB Sanggariang Kuningan, jadi saya harap yang akan saya teliti dalam penelitian ini bisa membangkitkan latihan yang saya inginkan dari footwork, kekuatan otot tungkai dan tinggi lompatan terhadap kemampuan smash.

Dari permasalahan yang terjadi di PB Sanggariang peneliti menyimpulkan bahwa sangat pentingnya latihan fisik bagi pebulutangkis remaja usia 15 tahun di PB Sanggariang, berikut latihan-latihan fisik yang bisa dilakukan untuk menunjang peningkatan fisik pebulutangkis $\mathrm{PB}$ Sanggariang, latihan footwork, latihan otot tungkai, dan latihan tinggi lompatan.

\section{METODE PENELITIAN}

Metode penelitian adalah cara yang digunakan oleh peneliti dalam mengumpulkan data penelitiannya. Sedangkan menurut Sugiyono (2011:3) penelitian adalah merupakan cara ilmiah untuk mendapatkan data dengan tujuan dan kegunan tertentu. Berdasarkan pengertian tersebut terdapat empat hal yang perlu dipahami lebih lanjut yaitu: cara ilmiah, data, tujuan dan kegunaan. Peneliti itu merupakan cara ilmiah, berarti peneliti itu di dasarkan pada ciri-ciri keilmuan rasional, empiris dan sistematis.

Penelitian korelasi dapat dipahami dengan mudah kalau disandingkan dengan penelitian sebab. Creswell (2008:3) berpendapat penelitian korelasi adalah penelitian yang memberikan kesempatan untuk memprediksi skor tertentu karena adanya skor yang lain dan menerangkan antar vaiabel. Berdasarkan pernyataannya ada dua kata kunci dalam penelitian korelasional, yaitu hubungan correlation dan prediksi atau ramalan prediction. Suatu korelasi adalah uji statistik untuk menentukan kecenderngan atau pola untuk dua atau lebih variabel atau dua set data bervariasi secara konsisten

Disamping itu peneliti ingin mengetahui suatu variabel. Jadi variable penelitian pada dasarnya adalah segala sesuatu yang berbentuk apa saja yang ditetapkan oleh peneliti untuk dipelajari, kemudian ditarik kesimpulan Sugiyono (2011:60). Dalam peneliti ini variabel yang dimaksud adalah: variabel (X) atau independen dalam peneliti adalah latihan footwork (shuttle run) otot tungkai (leg strength) tinggi lompatan (vertical jump). Variabel terikat adalah yang dipengaruhi atau menjadi akibat, karena adanya variable bebas (X) atau independen, variable terikat $(\mathrm{Y})$ independen dalam penelitian ini adalah hasil kemampuan smash.

Untuk mempermudah langkahlangkah yang harus dilakukan dalam penelitian, diperlukan design yang dijadikan pegangan agar peneliti tidak keluar dari ketentuan yang sudah ditetapkan sehingga tujuan atau hasil yang diinginkan akan sesuai dengan harapan dalam rangka mencapai tujuan tersebut, penulis dalam penelitian ini menggunakan korelasi. 
Gambar 1 Hubungan struktur $\mathrm{X}_{1}, \mathrm{X}_{2}$ dan $\mathrm{X}_{3}$ terhadap $\mathrm{Y}$

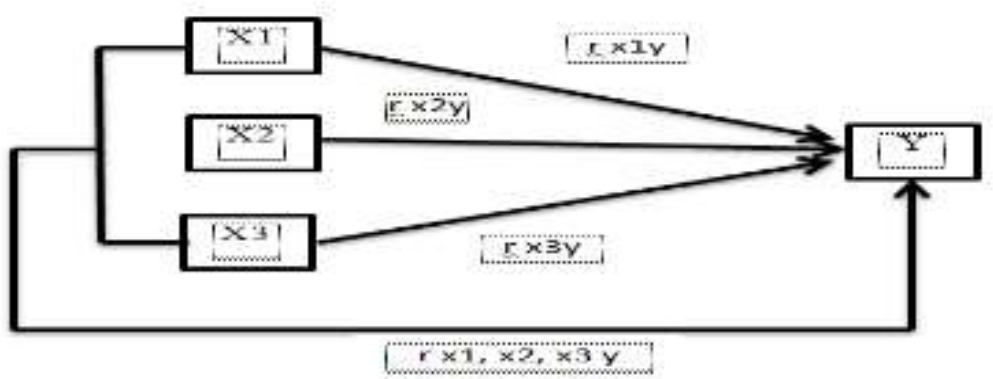

1. $\mathrm{X} 1$ terhadap $\mathrm{Y}=$ Hubungan antara footwork terhadap kemampuan smash dalam permainan bulutangkis $\mathrm{PB}$ Sanggariang.

2. $\mathrm{X} 2$ terhadap $\mathrm{Y}=$ Hubungan antara kekuatan otot tungkai terhadap kemampuan smash dalam permainan bulutangkis PB Sanggariang.

3. $\mathrm{X} 3$ terhadap $\mathrm{Y}=$ Hubungan antara tinggi lompatan terhadap kemampuan smash dalam permainan bulutangkis PB Sanggariang.

4. $\mathrm{X} 1, \mathrm{X} 2, \mathrm{X} 3$ terhadap $\mathrm{Y}=$ Hubungan antara footwork, kekuatan otot tungkai dan tinggi lompatan terhadap kemampuan smash dalam permainan bulutangkis PB Sanggariang.

Teknik pengumpulan data yang digunakan dalam penelitian ini adalah dengan penggunaan tes. Untuk mengukur ada atau tidaknya serta besarnya kemampuan objek yang diteliti maka digunakan korelasional. Menurut Gay (2000:4) penelitian korelasional kadang diperlakukan sebagai penelitian deskriptif, terutama disebabkan penelitian korelasional mendeskripsikan sebuah kondisi yang telah ada. Menurut dia, bagaimanapun, kondisi yang didiskripsikan berbeda secara nyata dari kondisi yang biasanya didiskripsikan dalam laporan diri atau studi observasi; suatu studi korelasional mendeskripsikan, dalam istilah kuanitatif tingkatan di mana variabelvariabel tersebut berhubungan.

Sementara itu Ricards (2007:5) memberikan definisi korelasi sebagai suatu ukuran kekuatan hubungan antara dua kumpulan data. Metode ini menggambarkan secara kuantitatif asosiasi ataupun relasi satu variabel dengan variabel lainnya. Misalnya kita ingin mengetahui antara nilai tes matematika sekelompoknya siswa dengan tinggi nilai ujian.

Berdasarkan definisi di atas, kata kunci dari penelitian korelasional adalah hubungan antar variabelvariabel. Artinya, penelitian ini mencoba untuk mengetahui sejauh mana tingkat hubungan dan kualitas hubungan antara variabel X1 Footwork, X2 Kekuatan Otot Tungkai, X3 Tinggi Lompatan, dan Y Kemampuan Smash.

Dalam penelitian ini untuk mengatahui hubungan antara variable digunakan uji korelasi untuk mengetahui hubungan Variabel $\mathrm{X}$ (Footwork, Kekuatan Otoot Tungkai, dan Tinggi Lompatan) terhadap Variabel Y (Kemampuan Smash). Penulis menggunakan korelasi product moment dengan rumus sebagai berikut :

$$
r x y=\frac{N \cdot \Sigma X i Y i \cdot(\Sigma X i)(\Sigma Y i)}{\sqrt{\left\{N . \Sigma X i^{2}-(\Sigma X i)^{2}\right)\left(N . \Sigma Y i^{2}-(\Sigma Y i)^{2}\right\}}}
$$


Keterangan :

rxy $=$ koefisien korelasi antara variabel $\mathrm{x}$ dan variabel y yang di korelasikan.

$\mathrm{X}=$ Skor rata-rata dari variabel $\mathrm{X}$

$\mathrm{Y}=$ Skor rata-rata dari variabel $\mathrm{Y}$

$\mathrm{N}=$ banyaknya data

Tabel 1 Interpretasi Koefisien Korelasi Nilai r Arikunto 2010:169

\begin{tabular}{cc}
\hline Interval Korelasi & Tingkat Hubungan \\
\hline $0,80-1,00$ & Sangat Tinggi \\
\hline $0,60-0,79$ & Tinggi \\
\hline $0,40-0,59$ & Cukup \\
\hline $0,20-0,39$ & Rendah \\
\hline $0,00-0,19$ & Sangat Rendah \\
\hline
\end{tabular}

\section{HASIL DAN PEMBAHASAN}

Dalam penelitian ini yang dijadikan sampel 10 orang atlet badminton usia remaja di PB Sanggariang Kuningan. Berdasarkan penelitian yang telah dilaksanakan di PB Sanggariang Kuningan dibawah ini dijelaskan hasil penelitian yang meliputi tes Footwork (shuttle run), kekuatan otot tungkai (leg press), dan Tinggi lompatan (vertical jump) atlet badminton remaja PB Sanggariang Kuningan disajikan pada tabel dibawah ini:
Setelah didapatkan nilai rata-rata dan simpangan baku dari keempat variabel, selanjutnya dilakukan uji normalitas. Pengujian ini dilakukan sebagai tahap awal menuju analisis ststistik. Jika data terdistribusi normal, maka analisis statistik lanjutannya menggunakan analisis parametrik, tapi apabila datanya tidak terdistribusi normal maka analisis lanjutannya menggunakan analisis nonparametrik. Hasil penghitungannya yang dilakukan dapat dilihat pada tabel sebagai berikut:

Tabel 2 Hasil Uji Normalitas Kelompok Test Variabel

\begin{tabular}{ccccc}
\hline Butir Test & $\mathrm{X}^{2}{ }_{\text {hitung }}$ & $\mathrm{X}^{2}$ Tabel & Kesimpulan & Keterangan \\
\hline Shuttle-run & 0,30 & 6,63 & $\mathrm{X}^{2}{ }_{\text {hitung }}>\mathrm{X}^{2}{ }_{\text {tabel }}$ & $\begin{array}{c}\text { Data berdistribusi } \\
\text { normal }\end{array}$ \\
\hline Leg Press & 0,30 & 6,63 & $\mathrm{X}^{2}{ }_{\text {hitung }}>\mathrm{X}_{\text {tabel }}{ }^{2}$ & $\begin{array}{c}\text { Data berdistribusi } \\
\text { normal }\end{array}$ \\
\hline Vertical Jump & 2,04 & 6,63 & $\mathrm{X}^{2}{ }_{\text {hitung }}>\mathrm{X}_{\text {tabel }}{ }_{\text {nat }}$ & $\begin{array}{c}\text { Data berdistribusi } \\
\text { normal }\end{array}$ \\
\hline $\begin{array}{c}\text { Kemampuan } \\
\text { Smash }\end{array}$ & 0,97 & 6,63 & $\mathrm{X}^{2}{ }_{\text {hitung }}>\mathrm{X}_{\text {tabel }}$ & $\begin{array}{c}\text { Data berdistribusi } \\
\text { normal }\end{array}$ \\
\hline
\end{tabular}

Langkah selanjutnya yang dilakukan adalah menghitung korelasi yang bertujuan untuk mengetahui seberapa besar hubungan antara variabel yang satu dengan variabel lainnya dengan menggunakan uji parametrik karena berdasarkan uji 
normalitas ternyata data normal. Hasil penghitungan korelasi dapat dilihat pada tabel berikut:

a. Apakah ada hubungan antara X1 dan Y

b. Apakah ada hubungan antara $\mathrm{X} 2$ dan $\mathrm{Y}$ c. Apakah ada hubungan antara X3 dan Y

d. Apakah ada hubungan antara $\mathrm{X} 1, \mathrm{X} 2$, $\mathrm{X} 3$ dan $\mathrm{Y}$

Berdasarkan rumusan masalah diatas terdapat hubungan antara $\mathrm{X} 1$ dan $\mathrm{Y}, \mathrm{X} 2$ dan $\mathrm{Y}, \mathrm{X} 3$ dan Y, X1, X2, X3 dan Y.

Tabel 3 Besarnya Hubungan Antara Variabel

\begin{tabular}{clcc}
\hline No & \multicolumn{1}{c}{ Variabel } & Korelasi & Interprentasi \\
\hline 1 & $\begin{array}{l}\text { Footwork (X1) dengan Kemampuan Smash } \\
(Y)\end{array}$ & 0,81 & Sangat Kuat \\
\hline 2 & $\begin{array}{l}\text { Vertical jump (X3) dengan } \\
\text { Kemampuan Smash (Y) }\end{array}$ & 0,85 & Sangat Kuat \\
\hline 3 & Footwork (X1) dengan Vertical Jump (X3) & 0,73 & Kuat \\
\hline 4 & $\begin{array}{l}\text { Leg Press (X2) dengan } \\
\text { Kemampuan Smash (Y) }\end{array}$ & 0,81 & Sangat Kuat \\
\hline 5 & Footwork (X1) dengan Leg Press (X2) & 0,58 & Sedang \\
\hline 6 & Leg Press (X2) dengan Vertical Jump (X3) & 0,73 & Kuat \\
\hline
\end{tabular}

Hasil pengolahan dan analisis statistik yang dilakukan menunjukkan bahwa terdapat hubungan yang signifikan antara footwork, kekuatan otot tungkai dan tinggi lompatan terhadap kemampuan smash. Berdasarkan pengolahan data yang telah dilakukan, diperoleh hasil sebagai berikut:

1. Hubungan footwork dengan kemampuan smash adalah sebesar 0,81 artinya kontribusi footwork terhadap kemampuan smash sebesar $65,61 \%$. Maka dapat disimpulkan bahwa terdapat hubungan footwork dengan kemampuan smash signifikan dan intrepentasi nya sangat kuat.

2. Hubungan kekuatan otot tungkai dengan kemampuan smash adalah sebesar 0,81 artinya kontribusi footwork terhadap kemampuan smash sebesar 65,61\%. Maka dapat disimpulkan bahwa terdapat hubungan kekuatan otot tungkai dengan kemampuan smash signifikan dan intrepentasinya sangat kuat.

3. Hubungan tinggi lompatan dengan kemampuan smash adalah sebesar 0,85 artinya kontribusi tinggi lompatan terhadap kemampuan smash sebesar $72,25 \%$. Maka dapat disimpulkan bahwa terdapat hubungan tinggi lompatan dengan kemampuan smash signifikan dan intrepentasi nya kuat.

4. Berdasarkan hasil penelitian diketahui bahwa secara bersama-sama hubungan ketiga variabel signifikan dengan nilai 0,90 atau sebesar $81 \%$. Maka dapat disimpulkan bahwa X1, X2, X3 dan Y terdapat hubungan.

\section{SIMPULAN}

Berdasarkan hasil pengolahan data dan pembahasan tentang Hubungan antara Footwork, kekuatan otot tungkai dan tinggi lompatan terhadap kemampuan smash dalam permainan bulutangkis PB. Sanggariang kuningan, maka penulis dapat menyimpulkan bahwa " Hubungan antara Footwork, kekuatan otot tungkai dan tinggi lompatan memberikan dampak positif terhadap kemampuan smash bulutangkis PB. Sanggariang Kuningan. 
1. Diketahui dari data Hubungan footwork dengan kemampuan smash adalah sebesar 0,81 artinya kontribusi footwork terhadap kemampuan smash sebesar 65,61\%. Maka dapat disimpulkan bahwa terdapat hubungan footwork dengan kemampuan smash signifikan dan intrepentasi nya sangat kuat.

2. Diketahui Hubungan kekuatan otot tungkai dengan kemampuan smash adalah sebesar 0,81 artinya kontribusi kekuatan otot terhadap kemampuan smash sebesar 65,61\%. Maka dapat disimpulkan bahwa terdapat hubungan kekuatan otot tungkai dengan kemampuan smash signifikan dan intrepentasinya sangat kuat.

3. Hubungan tinggi lompatan dengan kemampuan smash adalah sebesar 0,85 artinya kontribusi tinggi lompatan terhadap kemampuan smash sebesar $72,25 \%$. Maka dapat disimpulkan bahwa terdapat hubungan tinggi lompatan dengan kemampuan smash signifikan dan intrepentasi nya kuat.

Berdasarkan hasil penelitian diketahui bahwa secara bersama-sama dari ketiga variabel mempunyai hubungan yang sangat erat dan signifikan. Maka dapat disimpulkan bahwa hubungan antara footwork, kekuatan otot tungkai dan tinggi lompatan terhadap kemampuan smash permainan bulutangkis pb. Sanggariang ini mempunyai hubungan yang sangat erat dan signifikan.

\section{DAFTAR PUSTAKA}

Arikunto, Suharsimi. 2010. Prosedur penelitiaan suatu pendekatan praktik. Jakarta:Rineka Cipta

Creswell, W. John 2008. Educational Reaserch Design: Planing, Conducting, and Evaluation, Quantitative Reaserch 3th ed,. Pearson: New Jersey.

Harsono. 2008. Coaching dan AspekAspek Pskologis dalam Coaching. Jakarta:CV Tambak Kusuma

Adityatama, F. 2017. Hubungan Otot Tungkai, Mata Kaki Dan Otot Perut Dengan Ketepatan Menembak Bola. JUARA : Jurnal Olahraga, 2(2), 2341. Retrieved from http://jurnal.upmk.ac.id/index.php/jua $\underline{\mathrm{ra} / \mathrm{article} / \mathrm{view} / 37}$

Kurniawan, Kurniawan \& Ramadan, G., 2017. Pengaruh latihan plyometric terhadap hasil smash pada ekstrakurikuler bolavoli putra di sma negeri 1 luragung. Jurnal Juara Vol . 2 No . 2 Januari 2017, 2(2), 85-95.

Poole, James. 2013. Belajar Bulutangkis. Bandung: Pionir Jaya. Smart Way to Get Fit. New Jersey: Basic Health Publications, Inc. 